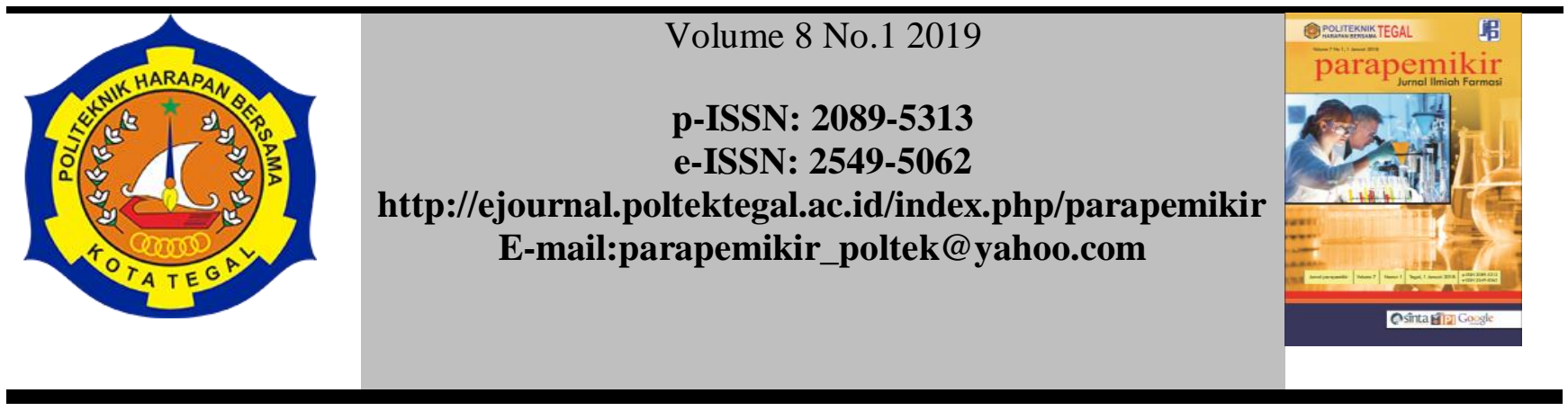

\title{
Uji Akivitas Imunomodulator Ekstrak Buah Petai (Parkia speciosa Hassk.) terhadap Titer Imunoglobulin (IgG) pada Mencit Balb/c yang Diinduksi dengan SDMD
}

\author{
Yithro Serang, M.Farm., Apt.*1, Ferika Indrasari S.Farm.,M.H.,Apt ${ }^{2}$ \\ ${ }^{1,2}$ Akademi Farmasi Nusaputera; Semarang; Telp/Fax 024-6747012 \\ e-mail: *1 ithoserang@gmail.com, ${ }^{2}$ ferikaindrasari89@gmail.com
}

\section{Article Info}

Article history:

Received

july 2017

Received in revised

form

July 2017

Accepted

August 2017

Available online

January 2018

\begin{abstract}
Abstrak
Imunomodulator adalah substansi atau obat yang dapat memodulasi fungsi dan aktivitas sistem imun Kebanyakan tanaman obat yang telah diteliti membuktikan adanya kerja imunostimulator, sedangkan untuk imunosupresor masih jarang dijumpai. Tanaman petai dapat berfungsi sebagai antioksidan. Ada hubungan yang erat antara antioksidan dan sistem imun pemberian antioksidan dapat menstimuli dan melindungi sistem imunitas seluler. Tujuan penelitian ini adalah untuk mengetahui pengaruh pemberian dan dosis efektif ekstrak etanol buah petai (Parkia speciosa Hassk) terhadap peningkatan titer IgG pada mencit Balb/c yang diinduksi dengan SDMD.
\end{abstract}

Metode Penelitian ini diawali dengan Petai dilakukan ekstraksi kemudian diuji kandungan kimia. Hewan percobaan terdiri dari 25 ekor mencit yang dibagi menjadi 5 kelompok perlakuan masing-masing kelompok terdiri dari 5 ekor mencit. Semuakelompok diimunisasi dengan SDMD 1\% sebanyak 0,2 ml/20 g BB pada hari ke-8 (setelah diaklimatisasi selama 7 hari) secara intravena. Sediaan uji diberikan peroral selama 7 hari. Pada hari ke-14 dilakukan pengambilan darah dari plexus retro orbitalis untuk pengumpulan serum dan diperiksa titer imunoglobulin $G$ dengan metode ELISA tidak langsung.

Manfaat yang ingin diperoleh dari penelitian ini adalah untuk membuktikan ekstrak etanol buah petai (Parkia speciosa Hassk) dapat meningkatkan sistim imun dalam melawan senyawa asing dengan peningkatan titer IgG pada mencit Balb/c yang diinduksi SDMD. Hasil Ekstrak Buah Petai Dosis 4,125 mg/KgBB, 8,25 mg/Kg $B B$ dan dosis $16,5 \mathrm{mg} / \mathrm{Kg}$ BB memberikan pengaruh terhadap peningkatan titer IgG. Dosis 16,5 mg lebih baik dari stimouno dalam meningkatkan kadar IgG mencit yang diinduksi SDMD. 


\section{Kata kunci-Petai}

(Parkia speciosa

Hassk), IgG,

SDMD, ELISA

Keywords-Petai

(Parkia speciosa

Hassk), $\operatorname{Ig} G$,

SDMD,ELISA

\begin{abstract}
Immunomodulators are substances or drugs that can modulate the function and activity of the immune system. Most of the medicinal plants that have been studied prove the presence of immunostimulators, while immunosuppressors are still rare. Petai plants can function as antioxidants. There is a close relationship between antioxidants and the immune system giving antioxidants can stimulate and protect the cellular immune system. The purpose of this study was to determine the effect of administration and effective dose of petai fruit (Parkia speciosa Hassk) ethanol extract on increasing IgG titer in Balb / c mice induced by SDMD.
\end{abstract}

This research method was started with Petai extraction and then tested for chemical content. Experimental animals consisted of 25 mice divided into 5 treatment groups, each group consisting of 5 mice. All groups were immunized with 1\% SDMD as much as $0.2 \mathrm{ml} / 20 \mathrm{~g} \mathrm{BB}$ on day 8 (after being acclimatized for 7 days) intravenously. Test preparation is given orally for 7 days. On day 14, blood collection from retro orbital plexus was performed to collect serum and examined immunoglobulin G titers with indirect ELISA method.

The benefit to be obtained from this study is to prove the ethanol extract of petai fruit (Parkia speciosa Hassk) can increase the immune system against foreign compounds with an increase in IgG titer in Balb / c mice induced by HRD. The results of Petai Fruit Extract Dosage $4.125 \mathrm{mg} / \mathrm{KgBB}, 8.25 \mathrm{mg} / \mathrm{Kg} B B$ and a dose of $16.5 \mathrm{mg} / \mathrm{Kg} \mathrm{BB}$ give an effect on increasing $\mathrm{IgG}$ titers. The dose of $16.5 \mathrm{mg}$ is better than stimouno in increasing IgG levels of mice induced by HRD

\footnotetext{
Alamatkorespondensi:
}

(O2018PoliteknikHarapanBersamaTegal

\section{Akademi Farmasi Nusaputera Semarang}

Jl. Medoho III No. 2 Semarang

Telp/fax. 024-6747012

p-ISSN: 2089-5313

E-mail: ithoserang@gmail.com

\section{PENDAHULUAN}

Lingkungan di sekitar manusia mengandung berbagai jenis organisme patogen, misalnya bakteri, virus, jamur, protozoa, dan parasit yang dapat menyebabkan penyakit pada manusia. Manusia memiliki sistem pertahanan tubuh yang lengkap untuk menghadapi serangan organisme pathogen, akan tetapi, munculnya manifestasi penyakit pada seorang individu tidak hanya dipengaruhi oleh organisme patogen tersebut. Proses munculnya manifestasi penyakit juga dipengaruhi oleh sistem pertahanan tubuh. Dalam keadaan optimal atau dalam keadaan sehat, sistim ini berfungsi secara efisien sehingga seseorang dapat terhindar dari dampak yang tidak menguntungkan akibat masuknya substansi asing. Apa bila ada kelainan dalam sistim pengaturan respon imun, seseorang mungkin tidak mampu melindungi tubuh dengan respon imun yang efisien, terlebih jika terjadi serangan agen infeksi yang ganas (Kresno 2001).

Imunomodulator adalah substansi atau obat yang dapat memodulasi fungsi dan aktivitas sistem imun. Imunomodulator dibagi menjadi 3 kelompok: i) imunostimulator, berfungsi untuk meningkatkan fungsi dan aktivitas sistem imun, ii) imunoregulator, artinya dapat meregulasi sistem imun, dan iii) imunosupresor yang dapat menghambat atau menekan aktivitas sistem imun. Kebanyakan tanaman obat yang telah diteliti membuktikan adanya kerja imunostimulator, sedangkan untuk imunosupresor masih jarang dijumpai. Pemakaian tanaman obat sebagai imunostimulator dengan maksud menekan atau mengurangi infeksi virus dan bakteri intraseluler, untuk mengatasi imunodefisiensi atau sebagai perangsang pertumbuhan sel-sel pertahanan tubuh dalam sistem imunitas (Block dan Mead 2003). 
Tanaman petai (Parkia speciosa Hassk) telah lama dibudidayakan diindonesia dan daunnya secara empiris telah digunakan untuk pengobatan. Biji petai mengandung vitamin $\mathrm{C}$ yang cukup banyak, senyawa fenolik yang dapat berfungsi sebagai antioksidan sehingga petai dapat dimanfaatkan sebagai sumber alami antioksidan (Amarnath, 2004). Ada hubungan yang erat antara antioksidan dan sistem imun. Banyak penelitian telah membuktikan bahwa pemberian antioksidan dapat menstimuli dan melindungi sistem imunitas seluler. Pemberian antioksidan seperti beta-karoten dapat meningkatkan aktivitas makrofag, melindungi makrofag dari kerusakan autooksidatif dan meningkatkan respon proliferasi limfosit T (Laily 2010).

IgG merupakan komponen utama imunoglobulin serum, dengan berat molekul 160.000 dalton. Kadarnya dalam serum sekitar $13 \mathrm{mg} / \mathrm{ml}$, merupakan $75 \%$ dari semua imunoglobulin (Baratawidjaja 2009). Dalam serum orang dewasa normal, IgG merupakan $75 \%$ dari imunoglobulin total dan dijumpai dalam bentuk monomer. Di antara semua kelas imunoglobulin, IgG paling mudah berdifusi ke dalam jaringan ekstravaskular dan melakukan aktivitas antibodi di jaringan. IgG pulalah yang umumnya melapisi mikroorganisme sehingga partikel itu lebih mudah difagositosis, di samping itu IgG juga mampu menetralisasi toksin dan virus.

Uji aktivitas system imun menggunakan metode titer antibodi merupakan gambaran sistem imun spesifik. Sistem imun spesifik atau sistim imun dapatan adalah sistem imun yang didapat karena terpapar patogen tertentu. Sistem imun dapatan sebagai pertahanan spesifik terhadap patogen penstimulasi dan memiliki kemampuan dalam mengingat patogen tersebut sehingga dapat mencegah terjadinya penyakit pada infeksi yang sama berikutnya (Roitt 2001). Metode yang dipakai dalam pengukuran titer antibodi terhadap immunoglobulin $\mathrm{G}$ (IgG) adalah ELISA tidak langsung.

Penelitian ini bertujuan untuk mengetahui dosis ekstrak buah petai yang dapat memberikan peningkatan titer IgG sebagai bagian dari sistim imun dalam melawan senyawa asing dalam hal ini SDMD yang diimunisasi pada mencit Balb/c. (Achyat 2008).

\section{METODOLOGI PENELITIAN}

\section{A. Pengambilan bahan}

Simplisia dibeli dalam keadaan segar di Bandungan, Semarang, selanjutnya dikeringkan dan dilakukan pembuatan serbuk dengan menggunakan mesin serbuk dan diayak dengan mess no 40.

\section{B. Ekstraksi}

Ditimbang sejumlah 500 g simplisia kering, ditambah etanol 96\% (3 kali bobot serbuk) kemudian dimasukan ke dalam bejana maserasi selama 3 hari sambil sesekali diaduk. Cairan hasil ekstraksi disaring dengan kertas saring. Ampas dimaserasi lagi dengan pelarut etanol, dilakukan dengan cara yang samadan diulangi beberapa kali hingga hasil maserat yang diperoleh telah jernih. Semua ekstrak dipekatkan dengan vakum evaporator.

\section{Pembuatan larutan Sel Darah Merah Domba (SDMD) $1 \%$}

Pemberian suspense SDMD $1 \%$ yang digunakan sebagai antigen pada mencit dimaksutkan untuk merangsang pembentukan antibody spesifik. Suspense SDMD $1 \%$ dipilih untuk imunisasi karna sifat antigeniknya yang tinggi dan antibodi yang terbentuk mudah diditeksi dengan reaksi presipitasi yang mudah dilakukan. Injeksi antigen ini dilakukan secara intraperitonium agar didapat reaksi dari respon imun yang cepat dan maksimum.Dosis SDMD yang digunakan pada mencit sebesar $0,2 \mathrm{ml} / 20 \mathrm{~g}$ BB mencit.

\section{Pembuatan Larutan Stimuno}

Stimuno digunakan sebagai kontrol positif. Satu sendok takar $(5 \mathrm{ml})$ Stimun $^{\mathrm{O}}{ }^{\circledR}$ mengandung $25 \mathrm{mg}$ ekstrak Phyllanthus niruri Linn Dosis Stimuno yang digunakan pada manusia adalah 2 sendok takar @ 25mg/5ml, 50mg dikonversikan ke hewan uji mencit didapatkan dosis untuk mencit sebesar $0,13 \mathrm{mg} / 20 \mathrm{~g} \mathrm{BB}$ mencit.

\section{E. Penyiapan hewan uji}

Hewan percobaan terdiri dari 25 ekor mencit yang dibagi menjadi 5 kelompok perlakuan masing-masing kelompok terdiri dari 5 ekor mencit. Kelompok I : mencit diimunisasi dengan SDMD 1\% secara intra peritonium dan ekstrak petai dosis $4,125 \mathrm{mg} / 20 \mathrm{~g}$ bb secara per oral. Kelompok II : mencit diimunisasi dengan SDMD 1\% secara intra peritonium dan ekstrak petai dosis $8,25 \mathrm{mg} / 20 \mathrm{~g}$ bb secara per oral. Kelompok III : mencit diimunisasi dengan SDMD 1\% secara intra peritonium dan ekstrak petai dosis $16,5 \mathrm{mg} / 20 \mathrm{~g}$ bb secara per oral. Kelompok IV : mencit Kontrol negatif diimunisasi dengan SDMD $1 \%$ secara intraperitonial.Kelompok $\mathrm{V}$ : mencit Kontrol positif diimunisasi dengan SDMD 1\% secara intra peritonium dan diberi stimuno secara per oral dengan dosis 0,55 $\mathrm{mg} / 20 \mathrm{~g} \mathrm{BB}$.

Semua kelompok diimunisasi dengan SDMD 1\% sebanyak 0,2 ml/20 g BB pada hari ke-8 (setelah diaklimatisasi selama 7 hari) secara intravena. Sediaan uji diberikan peroral selama 7 hari. Pada hari ke-14 dilakukan pengambilan darah dari plexus retro orbitalis untuk pengumpulan serum dan diperiksa titer imunoglobulin $\mathrm{G}$ dengan metode ELISA tidak langsung. 


\section{F. Pengujian Titer Imunoglobulin G dengan ELISA tidak langsung}

Serum darah mencit dari perlakuan diuji dengan metode ELISA tidak langsung. Microplate dilapisi dengan antigen $5 \mu \mathrm{g} / \mathrm{ml}$ dalam PBS (Phosphate Buffer Saline) sebanyak $100 \mu \mathrm{l}$ untuk setiap sumuran lalu diinkubasi semalam pada suhu $4^{\circ} \mathrm{C}$. Setelah dicuci dangan PBST 0,05\% sebanyak 4x $200 \mu$ l setiap sumuran, lempeng diblok dengan BSA (Bovine Serum Albumin) $0,5 \%$ dalam PBS dan diinkubasi selama 1 jam di incubator $37^{\circ} \mathrm{C}$. Lempeng dicuci $3 \mathrm{x}$ dengan PBST (Phosphate Buffer Saline Tween ${ }^{20}$ ) 0,05\% kemudian diisi serum dengan pengenceran 1:100 dalam PBS sebanyak $100 \quad \mu \mathrm{l}$ setiap sumuran. Setelah diinkubasi selama 2 jam di incubator $37^{\circ} \mathrm{C}$, lempeng dicuci $4 \mathrm{x}$ dengan PBST 0,05\%. Sebanyak $100 \mu \mathrm{l}$ konjugat alkaline phosphatase conjugate antimouse IgG dimasukkan ke setiap sumuran. Setelah inkubasi selama 2 jam di incubator $37^{\circ} \mathrm{C}$, lempeng dicuci $3 \mathrm{x}$ dengan PBST 0,05 \%. Substrat NPP (Nitro Phenil Phosphate) ditambahkan ke masing-masing sumuran sebanyak $100 \mu \mathrm{l}$ dan diinkubasi 15-20 menit di tempat gelap pada suhu kamar. Reaksi dihentikan dengan $\mathrm{H}_{2} \mathrm{SO}_{4} 2,5 \mathrm{M}$ sebanyak $50 \mu \mathrm{l}$ untuk setiap sumuran. OD dibaca dengan ELISA reader pada $\lambda 490 \mathrm{~nm}$ (Burgess 1995).

\section{G. Teknik Pengumpulan Data dan Analisis}

Hasil uji efek imunostimulan ekstrak petaiterhadap titer IgG yang diinduksi dengan SDMD 1\% dianalisis dan dihitung dengan menggunakan analisa ANOVA, dilakukan Uji Distribusi Normal (Kolmogorov smirnov) apabila nilai signifikasi lebih besar dari 0,05 maka data terdistribusi normal, dilanjutkan dengan Uji Homogenitas (Anova satu jalan). Bila nilai probabilitas Anova satu jalan kurang dari 0,05 maka ada beda nyata variasi dalam perlakuan.

\section{HASIL DAN PEMBAHASAN}

\section{Hasil Pemeriksaan Ekstrak Etanolik Buah Petai}

Hasil pemeriksaan ekstrak etanolik Buah Petai adalah bentuk kental (tidak dapat dituang), warnahijau pekat, dan rasa sepat.

\section{Identifikasi kandungan kimia}

Identifikasi ekstrak etanolik Buah Petaisecara kualitatif dilakukan di Laboratorium Akademi Farmasi Nusaputera. Hasil identifikasi terhadap ekstrak etanolik buah petai menunjukkan adanya kandungan senyawa kimia berupa saponin, terpenoid dan flavonoid.

\section{Hasil Pengujian ELISA}

ELISA merupakan salah satu dari teknik uji imunologi.Titer immunoglobulin dapat diukur menggunakan metode ELISA tidak langsung. Pemilihan metode ini karena ELISA tidak langsung merupakan konfigurasi paling sederhana untuk pengukuran titer antibodi. Pengukuran metode ELISA tidak langsung berdasarkan intensitas warna yang terbentuk dari oksidasi oleh enzim yang terdapat pada kompleks antigen-antibodiantiimmunoglobulin terhadap substrat. Ada beberapa tahap yang dilakukan pada pengukuran titer antibodi. Tahapan tersebut meliputi pelapisan antigen pada matriks padatan pendukung yaitu mikroplate ELISA 96 wells yang diinkubasi selama 24 jam pada suhu $4^{\circ} \mathrm{C}$ agar antigen terikat dengan maksimal pada plate. Setelah inkubasi selesai dilanjutkan dengan pencucian plate menggunakan $\mathrm{PBST}_{20} 0,05 \%$ (Phosphate Buffer Saline Tween $200,05 \%$ ) untuk menghilangkan partikel atau bahan dari luar yang tidak terikat pada matriks padat. Kemudian dilakukan blocking dengan menggunakan BSA (Bovine Serum Albumin) untuk memblok antigen yang sudah terikat pada matriks agar tidak hilang saat perlakuan selanjutnya dan dicuci kembali dengan $\mathrm{PBST}_{20} 0,05 \%$.

Tahap berikutnya adalah penambahan serum uji yang mengandung antibodi. Serum yang ditambahkan adalah serum yang telah diencerkan 100 kali dengan larutan PBS. Serum tersebut mengandung antibodi primer tidak berlabel, karena hewan uji pada perlakuan sudah diimunisasi maka serum yang mengandung antibodi sesuai akan berikatan dengan antigen yang sudah terlapiskan pada matriks. Selanjutnya plate diinkubasikan pada suhu $37^{\circ} \mathrm{C}$ selama 1,5 jam untuk mengkondisikan suhu tubuh manusia agar reaksi berjalan optimal, kemudian matriks dicuci dengan $\mathrm{PBST}_{20} 0,05 \%$.

Tahap berikutnya penambahan antibodi sekunder (konjugat antimouse $\operatorname{IgG}$ ) yang dilabeli enzim alkaline phosphatase pada matriks. Selanjutnya dilakukan inkubasi selama 1 jam pada suhu $37^{\circ} \mathrm{C}$ agar terbentuk kompleks antigen-antibodi-antiimunoglobulin berlabel enzim ( $\mathrm{Ag}$ $\left.A b-A b^{\mathrm{E}}\right)$. Kemudian plate dicuci kembali menggunakan larutan PBST $_{20} 0,05 \%$.

Tahap selanjutnya adalah penambahan substrat NPP $100 \mu$ lalu diinkubasi pada suhu kamar dalam ruangan gelap. Penginkubasian diruangan gelap bertujuan untuk memvisualisasi komplek dengan menghasilkan warna. Perubahan warna terjadi karena substrat teroksidasi oleh enzim alkaline phosphatase yang terdapat pada kompleks antigen-antibodi-antiimmunoglobulin berlabel enzim. Banyaknya substrat yang teroksidasi sebanding dengan banyaknya antibodi yang terdapat dalam kompleks, sehingga intensitas warna dapat dijadikan parameter untuk mengukur banyaknya antibodi yang terbentuk. Semakin tinggi intensitas warna maka semakin tinggi pula antibodi yang terdapat dalam sampel. Intensitas warna diukur menggunakan alat fotometer. Hasil pengukuran alat fotometer disebut optical density (OD), disajikan dalam tabel berikut: 
Tabel 1Optical density imunoglobulin G.

\begin{tabular}{|c|c|c|c|c|c|c|c|}
\hline \multirow[t]{2}{*}{ Kelompok } & \multirow[t]{2}{*}{ Perlakuan } & \multicolumn{5}{|c|}{ Replikasi } & \multirow{2}{*}{$\begin{array}{l}\text { Rata-rata } \\
\quad \pm S D\end{array}$} \\
\hline & & 1 & 2 & 3 & 4 & 5 & \\
\hline$I$ & $\begin{array}{l}\text { Ekstrak buah petai } \\
\text { dosis } 4,125 \\
\mathrm{mg} / \mathrm{KgBB}\end{array}$ & 1,092 & 1,062 & 0,956 & 1,020 & 0,995 & $1,025 \pm 0,071$ \\
\hline II & $\begin{array}{l}\text { Ekstrak buah petai } \\
\text { dosis } 8,25 \\
\mathrm{mg} / \mathrm{KgBB}\end{array}$ & 1,004 & 0,856 & 0.998 & 0,923 & 0,966 & $0,937 \pm 0,094$ \\
\hline III & $\begin{array}{l}\text { Ekstrak buah petai } \\
\text { dosis } 16,5 \mathrm{mg} / \mathrm{Kg} \\
\text { BB }\end{array}$ & 1,101 & 1,141 & 1,108 & 1,064 & 0,992 & $1,081 \pm 0,098$ \\
\hline$I V$ & $\begin{array}{l}\text { Kontrol (-) (CMC } \\
0,5 \%)\end{array}$ & 0,919 & 0,942 & 0,908 & 0,866 & 0,937 & $0,913 \pm 0,036$ \\
\hline V & $\begin{array}{l}\text { Kontrol (+) } \\
\text { (Stimuno) }\end{array}$ & 0,908 & 0,933 & 0,965 & 0,965 & 0,994 & $0,964 \pm 0,033$ \\
\hline
\end{tabular}

Berdasarkan penentuan OD IgG dari serum mencit menggunakan ELISA tidak langsung didapatkan rata-rata OD kelompok perlakuan ekstrak buah petai dosis 4,125 $\mathrm{mg}, \quad 8,25 \mathrm{mg}, 16,5 \mathrm{mg}$, secara berturut-turut sebesar $1,025 \pm 0,071 ; 0,937 \pm 0,094 ; 1,081 \pm 0,098$. Kelompok perlakuan kontrol negatif dan positif berturut-turut sebesar $0,913 \pm 0,036 ; 0,964 \pm 0,033$. Kontrol negatif memiliki ratarata OD paling rendah karena $\mathrm{cmc}$ memang tidak mempunyai aktifitas untuk meningkatkan titer IgG. Ekstrak buah petai dosis $16,5 \mathrm{mg} / \mathrm{Kg} \mathrm{BB}$ memiliki ratarata OD paling tinggi,

Peningkatan nilai OD berbanding lurus dengan peningkatan nilai kadar $\operatorname{IgG}$, semakin tinggi nilai OD nya maka Nilai Kadar IgG nya akan semakin besar.

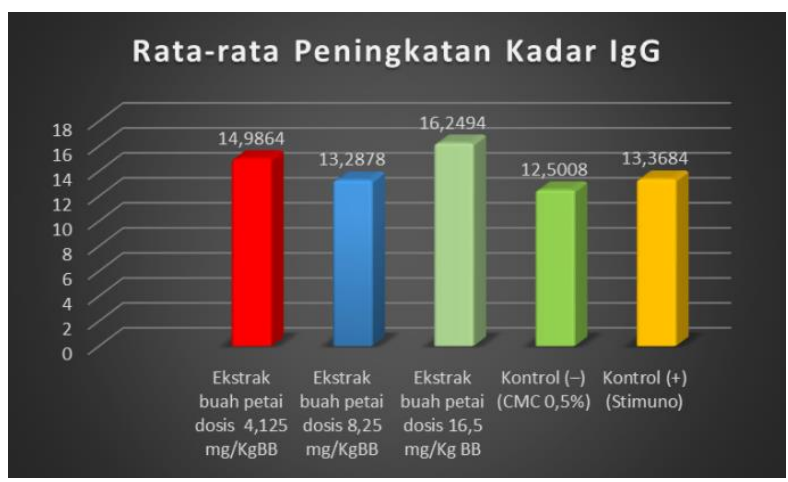

Gambar 1Rata-rata Peningkatan kadar IgG

Rata-rata nilaI peningkatan kelompok I, II, III lebih tinggi daripada rata-rata nilai peningkatan kontrol negatif, sehingga dapat disimpulkan perlakuan dengan ekstrak buah petai mampu meningkatkan titer immunoglobulin G.
Berdasarkan analisis statistik, CMC sebagai kontrol negatif berbeda nyata dengan ekstrak buah petai dosis 4,125 mg dan dosis 16,5 mg. kelompok kontrol positif menunjukkan peningkatan kadar yang signifikan ( $\mathrm{p}>0,05)$. Stimuno bekerja sebagai imunostimulan dengan meningkatkan sistim imun.namun, Stimuno sebagai kontrol positif tidak berbeda nyata dengan ekstrak dosis 4,125 mg dan ekstrak dosis 8,25 mg namun berbeda nyata dengan dosis ekstrak 16,5 mg. Artinya kemampuan stimuno dalam meningkatkan Titer Imunogloblin G sebanding dengan ekstrak buah petai dosis $4,125 \mathrm{mg} / \mathrm{Kg}$ $\mathrm{BB}$ dan dosis $8,25 \mathrm{mg} / \mathrm{Kg} \mathrm{BB}$. Sedangkan dosis ekstak buah petai $16,5 \mathrm{mg} / \mathrm{Kg} \mathrm{BB}$ memiliki kemampuan yang lebih baik dari stimono dalam hal meningikatkan titer IgG.

\section{KESIMPULAN}

Hasil penelitian menunjukan adanya pengaruh pemberian dan dosis efektif ekstrak etanol buah petai (Parkia speciosa Hassk) terhadap peningkatan titer IgG pada mencit Balb/c yang diinduksi dengan SDMD.Ekstrak Buah Petai Dosis 4,125 mg/KgBB, 8,25 mg/Kg BB dan dosis $16,5 \mathrm{mg} / \mathrm{Kg}$ BB memberikan pengaruh terhadap peningkatan titer IgG. Dosis $16,5 \mathrm{mg}$ lebih baik dari stimouno dalam meningkatkan kadar IgG mencit yang diinduksi SDMD.

\section{UCAPAN TERIMAKASIH}

Peneliti mengucapkan terima kasih kepada Direktorat Riset dan Pengabdian Masyarakat, Direktorat Jendral Penguatan Riset dan Pengambangan Kemetrian Riset, Teknologi, dan Pendidikan Tinggi yang telah membiayai penelitian ini pada tahun 2018 sehingga dapat terlaksana 
dengan baik. Ucapan terimakasih juga disampaikan kepada Akademi Farmasi Nusaputera Semarang yang telah menyediakan fasilitas dalam melakukan penelitian ini.

\section{REFERENSI}

[1]. Achyat, S.R., Sadikin, M., Jusman, S.W.A.J., Rusdi. 2008. Pengaruh Pemberian Minyak Buah Merah (Pandanus conoideus Lam) terhadap Imunitas Humoral Tikus (Ratus norvegicus L.) Galur Wistar Melalui Pengamatan Titer Antibodi Anti-SDMD. ISSN 1412-2855. Vol. 6.

[2]. Anonim, 2007. http://www.plantamor.com/index.php?plant=1377, diunduh pada tanggal 20 Maret 2012.

[3]. Baratawidjaja KG. 2009. Imunologi Dasar. Edisi VIII. Jakarta: Balai Penerbit Fakultas Kedokteran Universitas Indonesia. hlm 27-55, 140-176, 412-428, 515-528, 546-554, 560-561, 577-578.

[4]. Bellanti JA. (1993). Imunologi III. Penerjemah A.A. Wahab. Yogyakarta. Gajah Mada

[5]. Block, K.I. and M.N. Mead. 2003. Immune system effects of Echinacea, Ginseng and Astragalus: A review Integrative cancer therapies. 2(3): $247-267$.

[6]. Casc CL, Funke BR, Tortora GJ. 2001. Microbiology an introduction. San Francisco: $7^{\text {th }}$ Ed. Addison Wesley Longman. Inc.

[7]. Kresno SB. 2001. Imunologi : Diagnosis dan Prosedur Laboratorium. Ed ke-4. Jakarta: Balai Penerbit Fakultas Kedokteran Universitas Indonesia.

[8]. Laily N., 2010, Pengembangan Pangan Darurat Berigizi dan Berkhasiat Peningkat Daya Tahan Tubuh, Laporan Akhir Kegiatan Program Insentif, BPPT.

[9]. Roitt, I., J. Brostoff, and D. Male, 2001, Immunology, $10^{\text {th }}$ ed., Gower Medical Publ., London, 1-10.

[10]. Sheehan C. 1997. Clinical Imunology Priciple And Laboratory Diagnosis. $2^{\text {nd }}$ Ed. Lippincott Company. Philladelphia. New York.

[11]. Shukla dkk. (2009). Immunomodulatory activities of the ethanolic extract of Caesalpinia bonducella seeds. Journal of Ethnopharmacology 125. Page 252256.

[12]. Smith, Mangkoewidjaja. 1988. Pemeliharaan Pembiakan Hewan Percobaan di Daerah Tropis. Jakarta: UI Press.

[13]. Tjay TH, Rahardja K. 2002. Obat-Obat Penting. Jakarta: PT.Elex Media Komputindo.

[14]. Voigt, Rudolf. 1995. Buku Pelajaran Teknologi Farmasi. Ed ke- 5. Yogyakarta: Universitas Gadjah Mada Press. 